\title{
INTEGRATED GEOPHYSICAL AND GEOLOGICAL INVESTIGATIONS OF KARST STRUCTURES IN KOMBEREK, SLOVAKIA
}

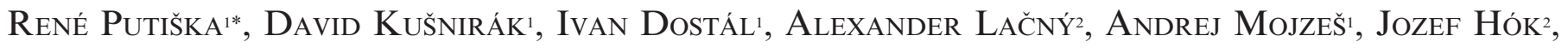 \\ Roman Pašteka ${ }^{1}$, Martin KrajŇÁK $^{1}$, And Marián BošAnskÝ ${ }^{1}$
}

\begin{abstract}
A complex of geophysical methods were used to investigate a small karst area aimed at the production of detailed geological mapping, to confirm geological localization of known sinkholes, and to find possible continuations of caves and voids below the surface. The dipole electromagnetic profiling and radiometric mapping (the gamma-ray spectrometry method) were applied to determine the spatial distribution of hard carbonate rocks and weathered valley-fill sediments. Detailed high-definition magnetometry was carried out at selected sites in the studied region with the aim of distinguishing between sinkholes and man-made lime-kilns, pits where limestone was heated and transformed into lime. The microgravity and the electrical-resistivity tomography (ERT) methods were used to create high-resolution images of the underground cave. The results of ERT and the geological survey were used as an initial model for gravity modeling. Subsurface cavities of various sizes are contrasting geophysical objects, and the electrical resistivity can range from very conductive to relatively resistive depending on the composition of the filling materials. The interpretation of resistivity properties is not always straightforward. We must distinguish air-filled (high-resistivity) and loamy water-filled (low-resistivity) cavities and fractures. The combined geophysical methodology permits us to determine a more accurate near-surface geological model, in our case the parallel interpretation of a strong conductive anomaly in the ERT inversion and a predominant density decrease in the gravity modelling yield the presence of cavities at depths approximately of 50 to $60 \mathrm{~m}$ below the surface.
\end{abstract}

\section{INTRODUCTION}

Explored caves are only a limited portion of those actually existing underground (White, 1990; Ford and Williams, 2007). To obtain information about these hidden caves, or unknown or inaccessible continuations of known caves, we must use indirect methods (Parise and Lollino, 2011; Margiotta et al., 2012; Pepe et al., 2013). Nearsurface geophysical methods have recently become an important tool in karst-caves research. The idea behind most of these geophysical methods is a material property of the void that is significantly different from the surrounding host rock and thus makes a material contrast. This material contrast can then be detected using a specific geophysical technique (e.g., Butler, 1984; Gibson et al., 2004; El-Qady et al., 2005; Dobecki and Upchurch, 2006; Nyquist et al., 2007; Mochales et al., 2008; Margiotta et al., 2012; Putiška et al., 2012a). Among some of the most frequently used geophysical techniques, electrical-resistivity tomography and microgravity can be mentioned, but additional methods can provide very useful information as well.

The studied region is located in the northeastern portion of the Malé Karpaty Mts., in the western part of Slovakia, and belongs to the Kuchyña-Orešany karst. The northeastern part of Kuchyňa-Orešany karst is represented by the Komberek karst, which is a not large, about $1 \mathrm{~km}^{2}$, but interesting karst plain, where two caves, the Strapek Cave and the Závrtová Priepast Cave, were discovered. Besides the caves, more than seventy terrain depressions were found in the area (Fig. 1), but some of them are not karst landforms, as they are man-made lime kilns. The lime kilns were created during the fifteenth and sixteenth centuries to produce quicklime through the calcination of limestone. The kilns are up to $3 \mathrm{~m}$ in diameter and 1-m deep, which is very similar to some of the smaller natural sinkholes in the area. Therefore, we tried to find a method to reliably distinguish them. Several depressions are filled with mud and water, which makes it difficult to distinguish whether their origin is natural or not. The term mudholes is used for these structures in the following text.

A variety of geophysical techniques can be used to detect the presence of caves and voids below the surface (Cardarelli et al., 2010; Gambetta et al., 2011; Kaufmann et al., 2011; Lačný et al., 2012; Andrej and Uroš, 2012).

\footnotetext{
${ }^{1}$ Department of Applied and Environmental Geophysics, Faculty of Natural Sciences, Mlynská dolina G, 84215 Bratislava, Slovak Republic

${ }^{2}$ Department of Geology and Paleontology, Faculty of Natural Sciences, Comenius University, Mlynská dolina G, 84215 Bratislava, Slovak Republic

*Corresponding Author: putiska@fns.uniba.sk
} 


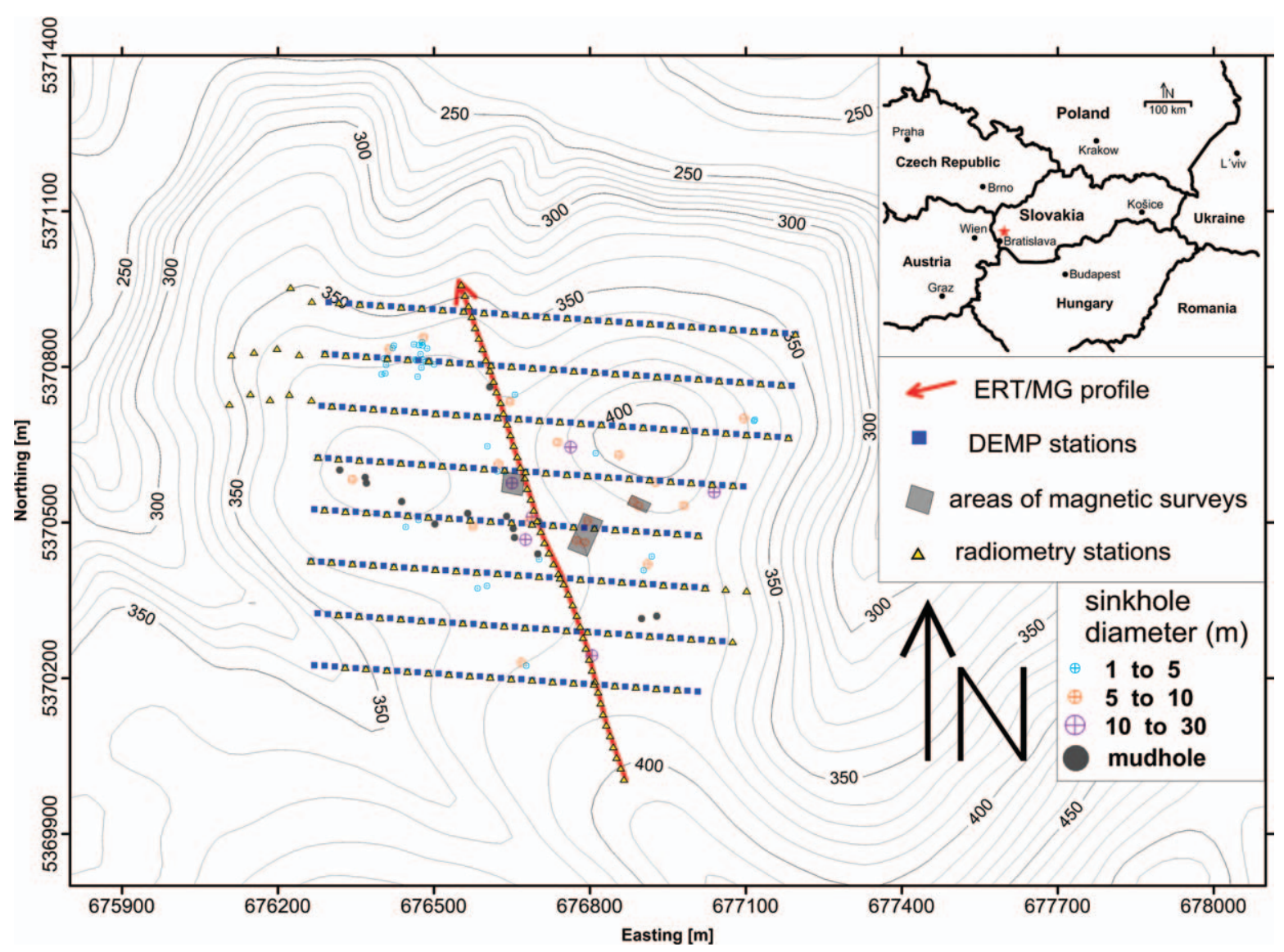

Figure 1. Topographic map of the study area showing the geophysical survey sites and karst structures. ERT is electricalresistivity tomography, MG is microgravity, and DEMP is surface electromagnetic conductivity. Coordinates in Figures 1-3 are UTM zone $33 \mathrm{~N}$.

Each are based on a physical contrast between a cave and the surrounding rocks. Karst features are prevalent throughout the study area. Sinkholes develop by a cluster of inter-related processes, including bedrock dissolution, rock collapse, soil sapping, and soil collapse. Any one or more of these processes can create a sinkhole. The basic classification (Walthman et al., 2005) has six main types of sinkholes, solution, collapse, caprock, dropout, suffusion, and buried, that relate to the dominant process behind the development of the sinkhole. The dominant type of sinkholes within the Komberek karst area is solution, formed where surface water and soil water dissolve bedrock near the surface as it flows towards points where it can sink into fissured or cavernous ground. As mentioned above, the primary focus of our geophysical research was to map the site and to detect geological anomalies. On the basis of these results the plan for deeper investigations was set up. The aim of the survey was to detect karst features like sinkholes or fractured zones that could communicate with the underground network. New caves or extensions of known galleries were expected to be found too. The location of the geophysical survey is shown in Figure 1.

\section{Geological Setting}

The Komberek karst area, as well as the Malé Karpaty Mts., are integral parts of the Western Carpathians orogenic belt. The Malé Karpaty Mts. geological structure consists of several tectonic units (Polák et al., 2011). The Tatricum tectonic unit is the most autochthonous unit comprising the Paleozoic crystalline basement and the Mesozoic sedimentary cover. The Fatricum and Hronicum tectonic units belong to the nappe structures of the Western Carpathians tectonically individualized during the Alpine orogeny during the Cretaceous period. The Tatricum unit in the studied area contains only the uppermost synorogenic flysch member, clayey shales, and turbiditic sandstones of Albian-Cenomanian age. An Upper Cretaceous thrust plane separates underlying Tatric from Fatric unit in its hanging wall. The Komberek area (Fig. 2) is built up almost exclusively by the Fatric unit's Middle to Upper Triassic and Jurassic members. Middle Triassic dark-grey to black thick-bedded Gutenstein type limestone is the prevailing rock type in this area, and it is also the lowermost part of Fatric unit. The tectonic contact between the Tatricum and the flysch sediments of the 


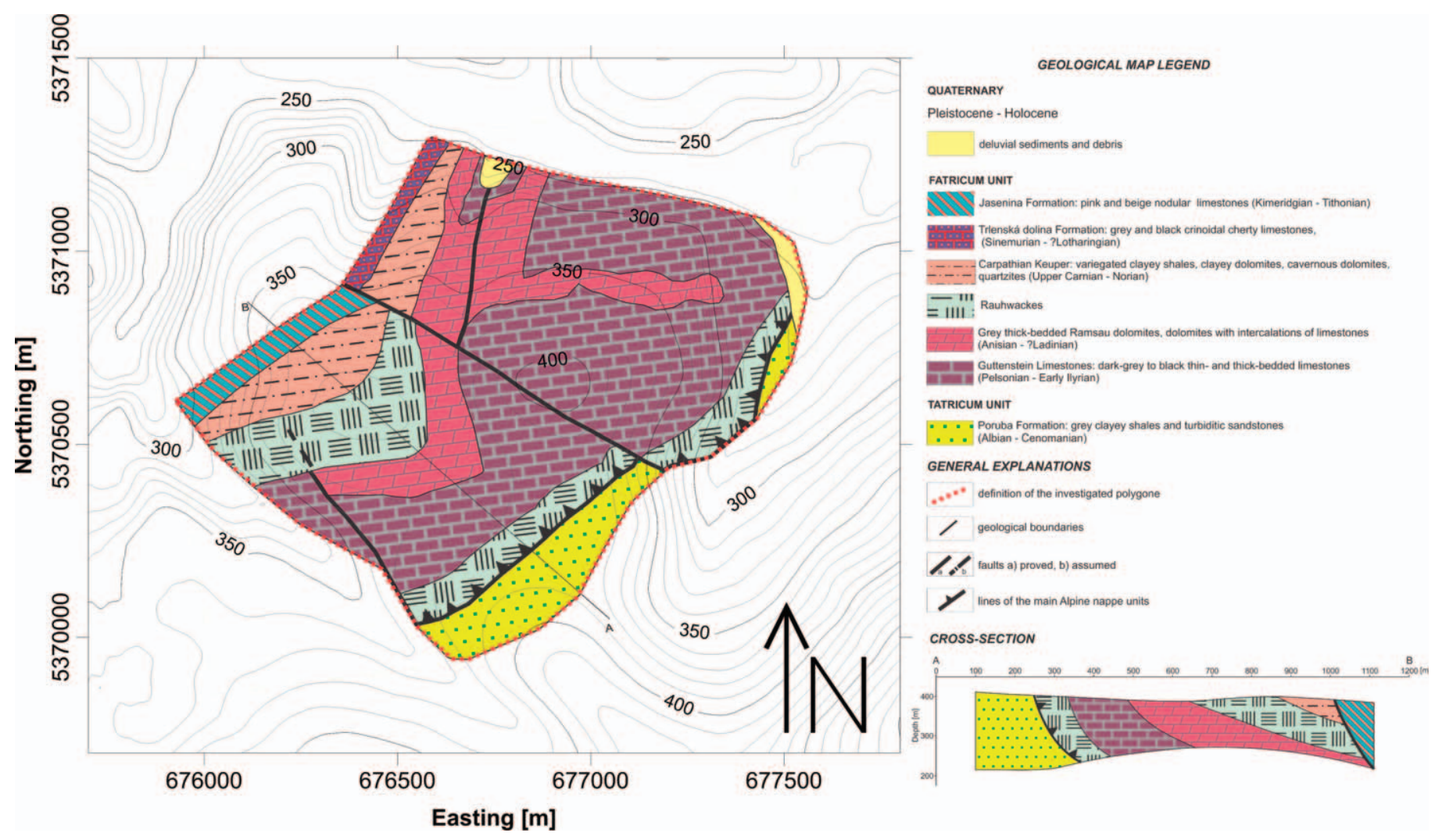

Figure 2. Geological map and cross-section of the Komberek area revised on the basis of the geological and geophysical investigations.

Fatricum units is linked to the rauhwackes. Rauhwackes (cornieules or cargneules) are breccias with a calcareous matrix and mainly dolomitic components that weather to form cavernous rocks. They are very often associated with tectonic contacts. The origin of rauhwackes is still controversial, but has been attributed to the weathering and alteration of dolomite-bearing evaporites, the tectonization of dolomites, or other processes (Krauter, 1971; Schaad, 1995). It is supposed that the rauhwackes are tectonically derived from the Gutenstein limestones. The Gutenstein limestones should be overlayed by Ramsau dolomites, but in this locality grey thick-bedded dolomitized limestones crop out. Variegated clayey shales, quartzy sandstones, and quartzstones, and also cavernous grey dolomites (rauhwackes) of Upper Triassic age belonging to Carpathian Keuper member overlie the Gutenstein and Ramsau carbonatic complex. In the northwestern part of the Komberek area there are Jurassic grey crinoidal cherty and pink nodular limestones. The Komberek area is disrupted by northwest-southeast oriented normal faults active during the Neogene (Polák et al., 2011). The sinkholes are localized along distinct lines situated along the litological and tectonic discontinuites. The main lithological discontinuity is between the Carpathian Keuper Formation and the Guttenstein limestones. The northwest-southeast tectonic line is the reason for the occurrence of the sinkholes array that follows it. An edited geological map is shown in Figure 2; because of the very flat morphology of the studied area and the scarcity of outcrops, geological mapping is very difficult.

\section{Geophysical Methods}

A complex of geophysical methods was designed to gather a large amount of geophysical information from the study area. The methods can be divided by purpose into two parts. The first part was an initial field investigation of the whole area. In this case, electromagnetic-conductivity, magnetometry, and gamma-ray spectrometry were used to map the site and to distinguish near-surface geological settings in the area. The information obtained was used to characterize the geological setting of the Komberek area (Fig. 2). The second part of the geophysical fieldwork included electrical-resistivity tomography (ERT) and microgravity survey on a selected profile across the karst area to obtain information about unknown or inaccessible continuations of known caves. The profile was based on the results from the geophysical work done during the first part of the investigation and also covers as many sinkholes and mudholes as possible (Fig. 1). During this stage, a

Journal of Cave and Karst Studies, December 2014•157 

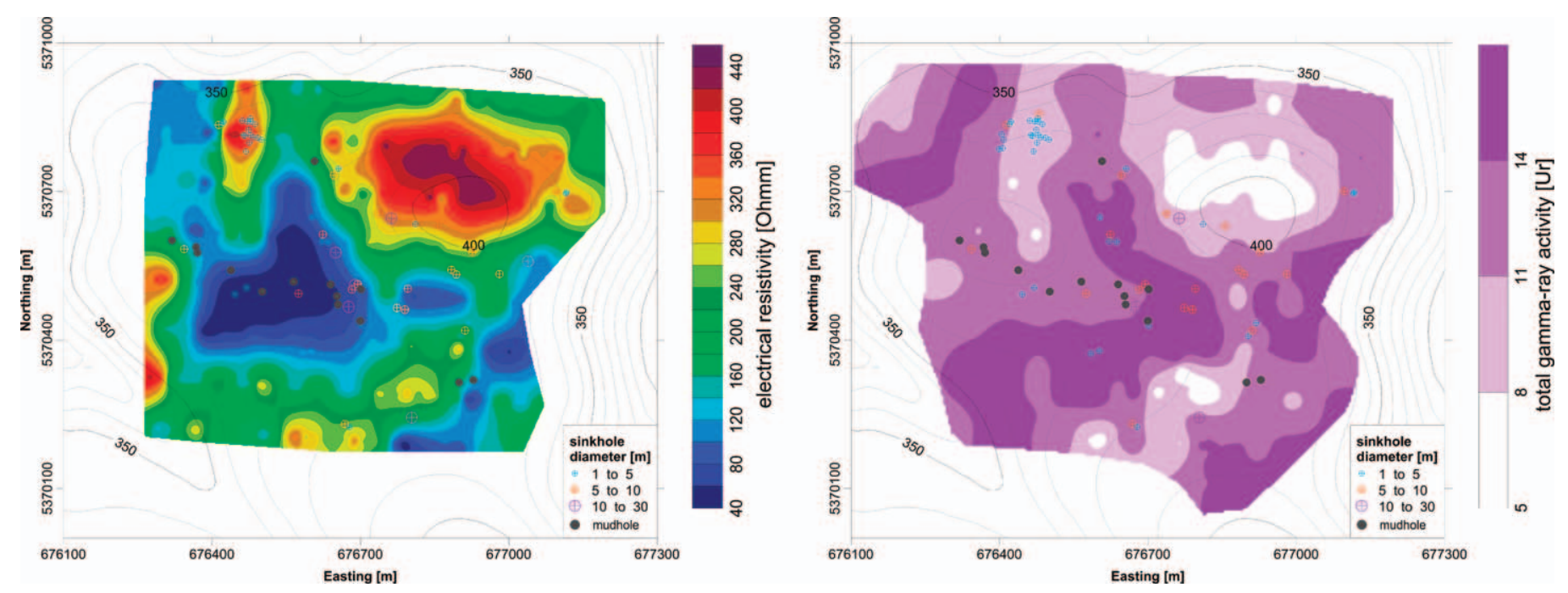

Figure 3. Result of surface electromagnetic conductivity and radiometry mapping. In the left-hand part is the map of apparent resistivity and the right-hand part is the map of total gamma-ray activity ( $\mathrm{Ur}$ is a unit of radioactivity, $1 \mathrm{Ur} \sim 1 \mathrm{ppm} \mathrm{eU}$ ).

detailed magnetometry survey was performed on selected sinkholes, to distinguish between natural and human-made sinkholes.

All geophysical works were done simultaneously by measuring the coordinates using GPS or a total station. The coordinate system used in the figures is UTM, zone $33 \mathrm{~N}$.

A profile survey by the ground gamma-ray spectrometry method was used to study the radioactivity of rocks, soils, and covers in the study area. This method allowed us to determine four measures of gamma-ray activity of nearsurface rock and soil horizon at each measured station: total gamma-ray activity eUt [Ur] ( $\mathrm{Ur}$ is a unit of radioactivity, $1 \mathrm{Ur} \sim 1 \mathrm{ppm}$ eU), concentration of ${ }^{40} \mathrm{~K}$ $[\% \mathrm{~K}]$, concentration of ${ }^{238} \mathrm{U}$ [ppm eU], and concentration of ${ }^{232} \mathrm{Th}$ [ppm eTh] where the letter "e" represents equivalent. The depth range is relatively shallow, no more than $1 \mathrm{~m}$ from the surface, but the method gives useful information mainly for geological mapping purposes. In situ measurements were carried out using a portable 256channel gamma-ray spectrometer GS-256 (Geofyzika Brno, former Czechoslovakia) with $3^{\prime} \times 3^{\prime} \mathrm{NaI}(\mathrm{Tl})$ scintillation detector using a traditional ground survey procedure: grass, old leaves, and the thin uppermost humus soil layer were removed and ground surface was levelled in a circle area of 1 to $1.5 \mathrm{~m}$ in diameter at each measured station. Time of measurement was 2 minutes per station. In total, 226 stations were measured along eight parallel westeast profiles (PF1 - PF8) approximately 100-m apart and one transverse northwest-southeast profile (PF9) (Fig. 1) with a 40-m step between measurements. The other geophysical methods were carried out at the same stations on the profiles, controlled by GPS measurements.

Electromagnetic-conductivity mapping (DEMP, for Dipole ElectroMagnetic Profiling) was performed on the eight parallel profiles with lengths from $900 \mathrm{~m}$ to $740 \mathrm{~m}$. The sampling interval of the measurement was $20 \mathrm{~m}$, so the whole dataset covers 289 points. The measurement was done with a CMD-4 instrument manufactured by GF Instruments Inc. (Czech Republic), which has dipole center distance of $3.77 \mathrm{~m}$, so the median depth of the electromagnetic investigation was around $6.0 \mathrm{~m}$. The depth range for most of the points allowed us to reach the bedrock in the area with a negligible effect from the sediments. The most important advantage of electromagnetic conductivity is the possibility of obtaining quick and useful results that match very well with DC resistivity methods.

The 2D electrical-resistivity tomography line (Fig. 1) was collected using an ARES instrument (GF Instruments Inc.). The survey was $1006.5-\mathrm{m}$ long and conducted with a dipole-dipole array with $5.5-\mathrm{m}$ electrode spacing. The 88 electrodes were used simultaneously, with alternation of two current and two potential electrodes and a roll-along survey. For post-processing and data interpretation, the inversion program RES2DINV (Loke and Barker, 1996) was applied. It generates a topographically corrected twodimensional resistivity model of the subsurface by inverting the data obtained from electrical imaging (Putiška et al., 2012a). A robust inversion ( $L_{1}$ norm) was used because it is more suitable for detecting caves and sharpening linear features such as faults and contacts within complex geological settings of karst regions.

The same profile from the ERT method has been used for the microgravity survey and the stations were placed next to each electrode. The instrument used for this method was a single Scintrex CG-5 unit with a resolution of $1 \mu \mathrm{Gal}$ $\left(10^{-8} \mathrm{~m} \mathrm{~s}^{-2}\right)$. Due to thick vegetation cover in the area, it was not possible to measure the positions of the stations using differential GPS, therefore the locations of the gravity stations and nearby topography was obtained 


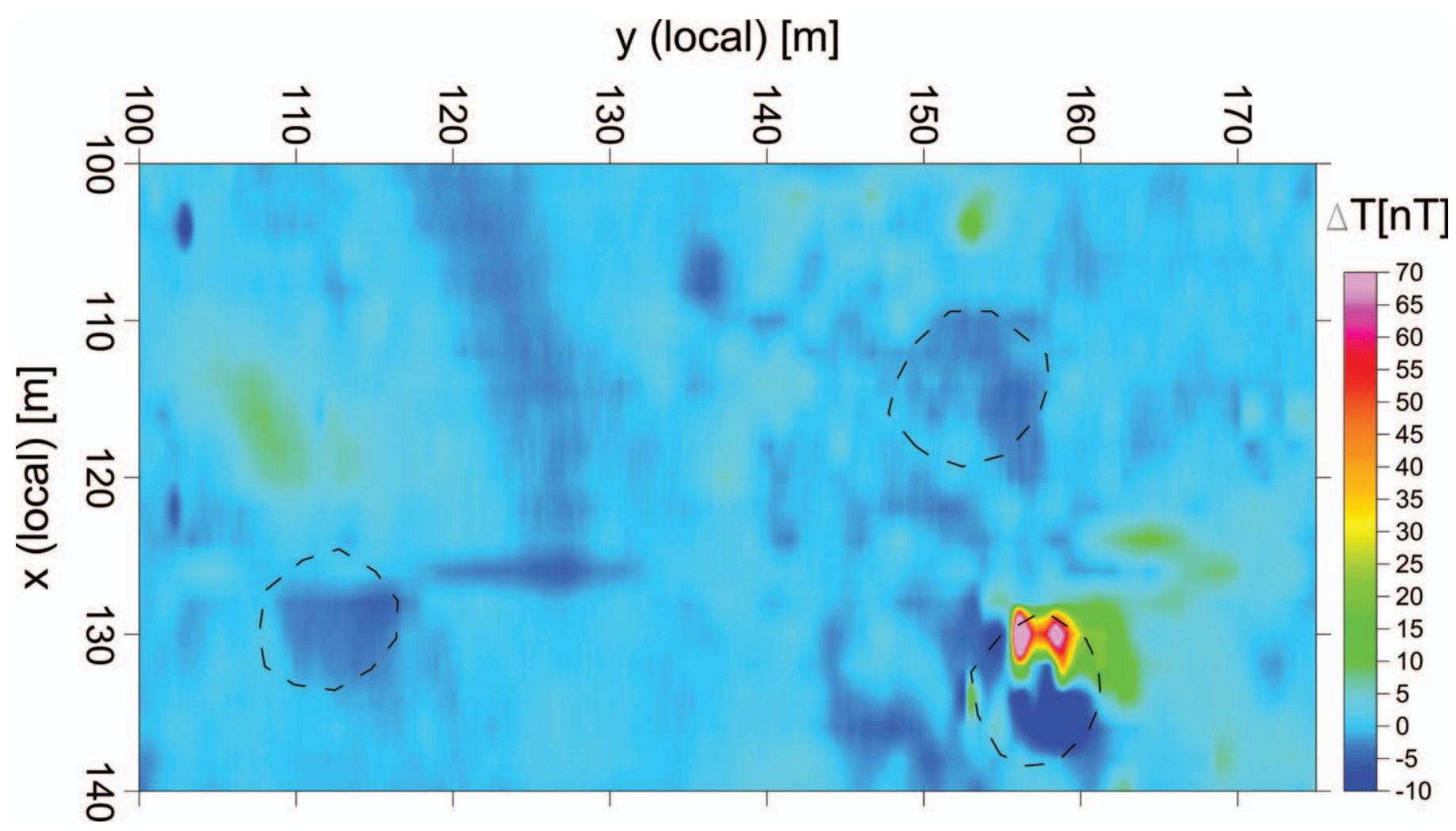

Figure 4. Results from one of the detailed magnetometry surveys. Terrain depression boundaries are shown by dashed lines. The depression in the lower right is shown to be an old lime kiln by the relatively strong dipole anomaly.

using Trimble M3 and Trimble S8 total stations tying to several GPS points in the vicinity of the profile. A total number of 184 gravity readings were processed to remove instrument drift, which was determined by repetitive measurement at the base station located in the center of the profile over a period of 2 hours and afterwards processed into form of complete Bouguer anomaly (Fig. 1).

Detailed high-definition magnetometry using a Csvapour magnetometer TM-4 with $0.2-\mathrm{m}$ sampling step on lines 1-m apart was realized at selected sites of the studied region with the aim to distinguish between sinkholes and man-made lime kilns. Selected sinkholes are highlighted in the Figure 1 with grey rectangles that reflect the actual area surveyed by detailed magnetometry. The survey rectangles for detailed magnetometry on three sites were chosen due to practical reasons. The first two sites were placed on the largest sinkhole in the Komberek area and on a known man-made lime kiln identified by the burned lime residuals and ashes inside it. As the last site, a swarm of terrain depressions of uncertain origin, was chosen.

\section{RESULTS AND INTERPRETATION}

The apparent resistivity map (Fig. 3) was obtained using the electromagnetic conductivity method (DEMP). The results show a good contrast between the highresistivity areas composed of dolomite and limestone and the low-resistivity ones that are the effect of Quaternary sediments concentrated in the topography depressions. The majority of the largest sinkholes are concentrated on the boundary between low and high resistivity areas. This boundary was chosen for microgravity and ERT surveys. Results from the radiometric mapping are shown as a map of total gamma-ray activity (Fig. 3). The contour map of the total gamma-ray activity eUt distribution shows very good agreement with the picture of the apparent resistivity distribution for rocks and soils in the study area, as obtained by surface electromagnetic conductivity mapping (DEMP) measurement (Fig. 3). Lower-radioactivity areas correspond to higher-resistivity areas in maps and vice versa. Simultaneously both physical fields show good correlation with terrain topography in the study area (Fig. 3). Positive topographic features are mostly characterized by higher electrical resistivity and lower total gamma-ray activity values, whereas negative terrain features mostly show lower resistivity and higher total gamma-ray activity. This relationship is, of course, strictly determined by the geological structure of the area (Fig. 2), since the hard carbonates form topographical elevations characterized by higher electrical resistivity and lower total gamma-ray activity. Weathered rocks and Quaternary sediments fill topographic depressions in the central and southwestern parts of the study area, which are characterized by lower electrical resistivity and higher total 

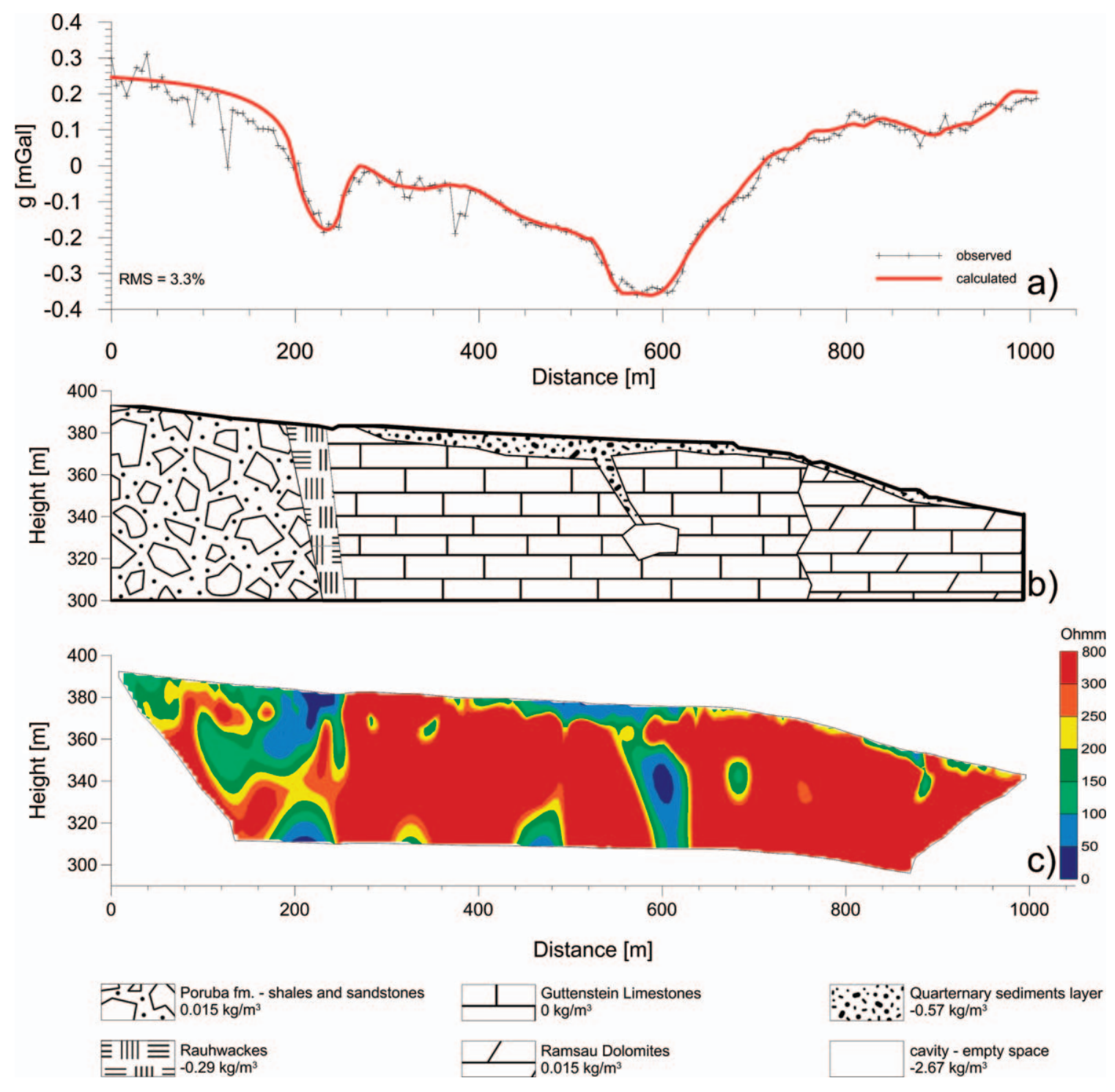

Figure 5. Results of the electrical-resistivity tomography and gravity modeling. The upper part of the figure (a) shows the correlation between the observed residual Bouguer anomaly and the model shown in the middle part (b). The ERT cross-section image is in the lower part of the figure (c).

gamma-ray activity. Generally, the two maps, the resistivity and the radioactivity, are quantitatively opposed to each other. In this way, the electromagnetic and radiometric surveys successfully outlined the boundary between valley fill and the carbonate rocks dolomite and limestone.

The total-field magnetic-anomaly map of the last of the survey rectangles is shown in Figure 4. The aim of the magnetic survey was to reveal contrast between sinkholes and man-made lime kilns. Due to the remnant magnetization produced during the heating processes we were able to easily recognize, based on qualitative interpretation, the lime kilns as having relatively strong dipole anomalies, as in the lower right of Figure 4.

Gravity and electrical-resistivity tomography methods were employed after the resistivity and radioactivity studies to detect possible cavernous structures in the selected profile across the whole area. Such caves can be empty, full, partly water-filled, or filled with a different kind of sediment. Air, water, or sediment-filled voids have a much lower density (air $0 \mathrm{~kg} \mathrm{~m}^{-3}$, water $1000 \mathrm{~kg} \mathrm{~m}^{-3}$, or sediment $\sim 2000 \mathrm{~kg} \mathrm{~m}^{-3}$ ) than the host rock for which the density of $2670 \mathrm{~kg} \mathrm{~m}^{-3}$ has been assigned. This difference in density is very significant and can be easily traced by gravity survey. Gravity, as an integral method, provides only information about the bulk composition of the subsurface. Therefore additional constraints are needed to model the Bouguer anomaly with appropriate structures. Electrical resistivity tomography is a reasonable choice due to the low cost of the survey and the high resistivity contrast that exists between an air-filled cavity 


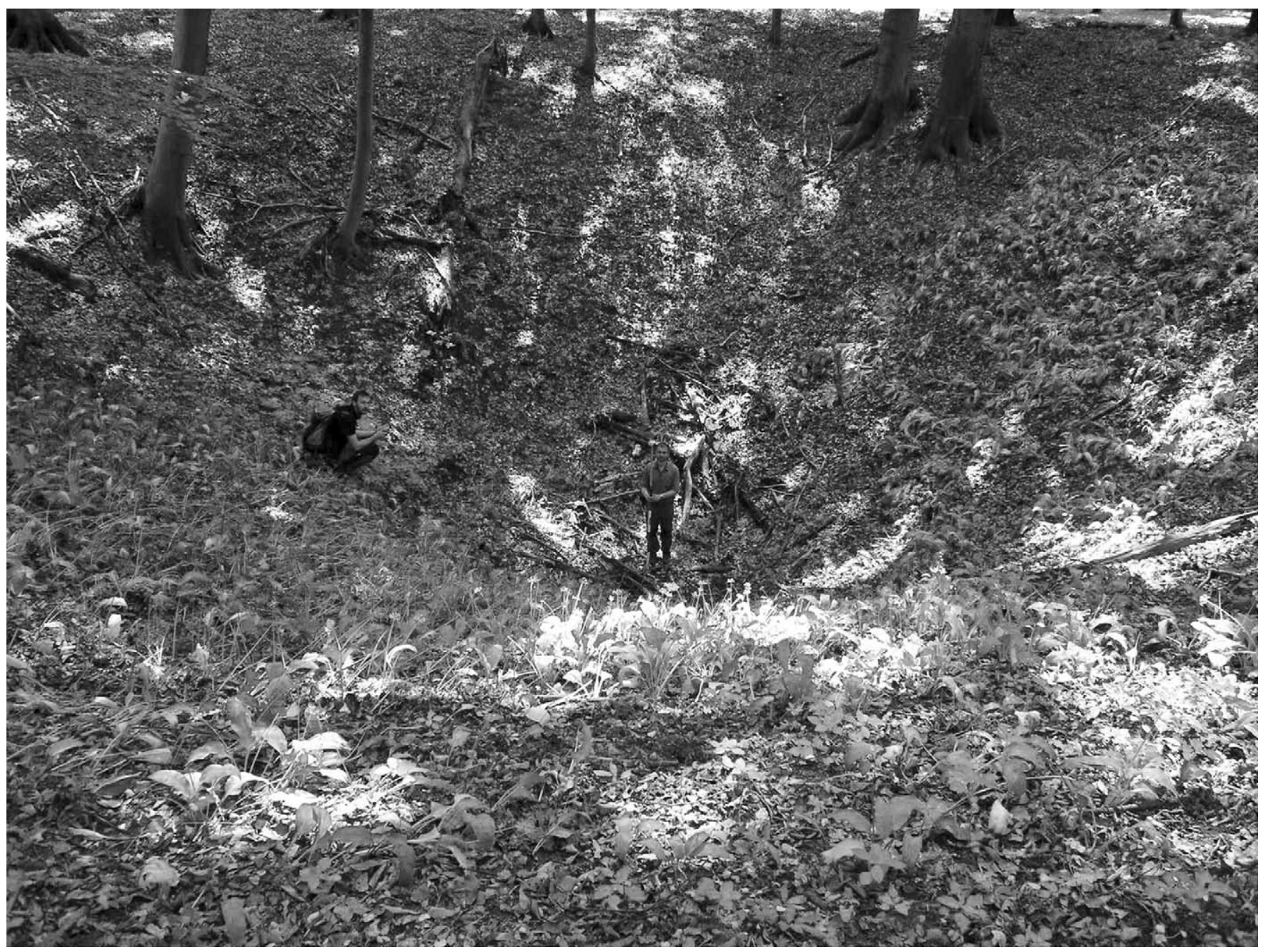

Figure 6. The sinkhole close to the electrical-resistivity tomography and microgravity line through the Komberek area. Diameter and depth of the sinkhole are $\sim 25 \mathrm{~m}$ and $9 \mathrm{~m}$, respectively.

and the surrounding formation (Zhou et al., 2002; Andrej and Uroš, 2012). Cavities can be also partially or completely water- or sediment-filled and, depending on the composition of the water, they might show a resulting electrical conductivity ranging from very conductive to relatively resistive compared to the host rock (Putiška et al., 2012b). The results of ERT and geological surveys were used as entries for the gravity modelling (Fig. 5). Gravity modelling was performed using the residual Bouguer anomaly computed for a reference density of $2670 \mathrm{~kg} \mathrm{~m}^{-3}$. The zero elevation has been used as a lower boundary for the model, with 2-D geometry except the cavity body, which was modelled as a $2.5-\mathrm{D}$ object with a lateral extension of $70 \mathrm{~m}$ and its center placed on the profile. To keep the model as simple as possible, only the most important features were taken into consideration, where the main structure of the lithological units was adopted from the geological map of the area. Received differential densities used for the model are shown in Fig. 5. Two important low density and low resistivity structures that can be important for the identification of karst structures were detected.

Figure $5 \mathrm{~b}$ shows the final model, obtained from the combined interpretation of the microgravity (Fig. 5a) and ERT measurements (Fig. 5c). From microgravity (Fig. 5a) two important low density structures have been detected. The first Bouguer gravity minimum, with its center located on profile length $225 \mathrm{~m}$ and amplitude of $-0.2 \mathrm{mGal}$, is associated with the geological setting in the area. The negative anomaly is produced from the lower gravity effect of the rauhwackes, which are porous and therefore have lower density (Fig. 2, Fig. 5b). The second, more significant minimum on the residual Bouguer anomaly curve, with amplitude lower than $-0.35 \mathrm{mGal}$ and center located at around $575 \mathrm{~m}$, seems to be more interesting from a speleological point of view, as no gravity anomalies resulting from geology were expected there. Comparing the results with the ERT image, a strong conductive anomaly is visible at the same point on the profile as the main gravity minimum (Fig. 5a, c), where we inserted a

Journal of Cave and Karst Studies, December 2014•161 
body representing an empty cave in Figure 5b. Empty space usually produces a high-resistivity anomaly in an ERT image, but in some special cases, as when the cave is partly filled with conductive material such as clay, the overall anomaly produced from the empty space can be conductive (Putiška et al., 2012b). The cave body in the final model (Fig. 5b) is connected to the ground by a communication channel, and its presence is also visible from the ground, where one of the largest sinkholes (diameter $\sim 25 \mathrm{~m}$ ) in the Komberek area was found (Fig. 6). The inverted ERT model (Fig. 5c) shows carbonate rock with a significantly higher resistivity $(500 \mathrm{Ohm} \mathrm{m})$ than the loamy material in the sinkhole, because of its considerably smaller primary porosity and fewer interconnected pore spaces. Loamy materials can hold more moisture and have higher concentrations of ions to conduct electricity; therefore, their resistivity values are below 100 $\mathrm{Ohmm}$. The high contrast in resistivity values between carbonate rock and loamy material makes it possible to use electrical resistivity to determine the underground structure.

\section{Conclusions}

A geomorphological analysis of the Komberek area identified more than 70 topographic depressions. However, not all of them are karst landforms, as man-made lime kilns are also present in the area. Detailed high-definition magnetometry was successfully employed to distinguish between natural sinkholes and man-made lime kilns (Fig. 4). Results from the radiometric mapping and dipole electromagnetic profiling, supported by geological mapping, allowed us to refine the geological boundaries of the lithological units within the Komberek karst area (Fig. 2). By means of the resistivity tomography and microgravity methods, the final geological cross-section model of the area was constructed (Fig. 5b). The Bouguer anomaly curve (Fig. 5a) shows two dominant negative anomalies that were interpreted by introducing ERT inverse model and gravity forward modelling. The first negative anomaly, with center located at profile location $225 \mathrm{~m}$ and amplitude of $-0.2 \mathrm{mGal}$, is associated with a presence of the porous rauhwackes formation and seems to be unimportant from a speleological point of view. The second major negative anomaly, with amplitude more than $-0.35 \mathrm{mGal}$ and center located at $\sim 575 \mathrm{~m}$, correlates with a conductive anomaly in the ERT inverse image at depth of $\sim 60 \mathrm{~m}$, where a cavity was detected. Lateral placement of this anomalous area is linked the presence of the largest sinkhole in the Komberek karst area. According to the results obtained from this study, we can conclude that microgravity together with electrical resistivity tomography have proved to be effective tools for imaging subsurface cavities in limestone at shallow depths. Thus, we believe that the presented methods and evaluation techniques could be successfully applied to other karst areas and potentially help in identifying hidden voids that possibly constitute karst hazards (see Parise and Gunn, 2007; De Waele et al., 2011 and references therein).

\section{ACKNOWLEDGMENTS}

The authors would like to thanks to an anonymous reviewer for his helpful comments that improved the final manuscript and to the Slovak Research and Development Agency APVV (Grant Nos. APVV-0194-10, APVV062511, APVV-0099-11, APVV-0129-12) and the Slovak Grant Agency VEGA (Grant Nos. 1/0095/12, 2/0067/12, 1/0747/ $11,1 / 0712 / 11,1 / 0131 / 14)$ for the support of their research.

\section{REFERENCES}

Andrej, M., and Uroš, S., 2012, Electrical resistivity imaging of cave Divaška jama, Slovenia: Journal of Cave and Karst Studies, v. 74, no. 3, p. 235-242. doi:10.4311/2010ES0138R1.

Butler, D.K., 1984, Microgravimetric and gravity gradient techniques for detection of subsurface cavities: Geophysics, v. 49, p. 1084-1096. doi:10.1190/1.1441723.

Cardarelli, E., Cercato, M., Cerreto, A., and Di Filippo, G., 2010, Electrical resistivity and seismic refraction tomography to detect buried cavities: Geophysical Prospecting, v. 58, p. 685-695. doi:10.1111/j.1365-2478.2009.00854.x.

De Waele, J., Gutiérrez, F., Parise, M., and Plan, L., 2011, Geomorphology and natural hazards in karst areas: a review. Geomorphology, v. 134, no. 1-2, p. 1-8. doi:10.1016/j.geomorph.2011.08.001.

Dobecki, T.L., and Upchurch, S.B., 2006, Geophysical applications to detect sinkholes and ground subsidence: The Leading Edge, v. 25, p. 336-341. doi:10.1190/1.2184102.

El-Qady, G., Hafez, M., Abdalla, M.A., and Ushijima, K., 2005, Imaging subsurface cavities using geoelectric tomography and ground-penetrating radar: Journal of Caves and Karst Studies, v. 67, no. 3, p. $174-181$.

Ford, D.C., and Williams, P., 2007, Karst Hydrogeology and Geomorphology: Chichester, John Wiley \& Sons Inc., 576 p.

Gambetta, M., Armadillo, E., Carmisciano, C., Stefanelli, P., Cocchi, L., and Tontini, F.C., 2011, Determining geophysical properties of a near-surface cave through integrated microgravity vertical gradient and electrical resistivity tomography measurements: Journal of Cave and Karst Studies, v. 73, no. 1, p. 11-15. doi:10.4311/jcks2009ex0091.

Gibson, P.J., Lyle, P., and George, D.M., 2004, Application of resistivity and magnetometry geophysical techniques for near-surface investigations in karstic terranes in Ireland: Journal of Cave and Karst Studies, v. 66 , no. 2 , p. $35-38$.

Kaufmann, G., Romanov, D., and Nielbock, R., 2011, Cave detection using multiple geophysical methods: Unicorn cave, Harz Mountains, Germany: Geophysics, v. 76, no. 3, p. B71-B77. doi:10.1190/1.3560245.

Krauter, E., 1971, Zur Genese rauhwackiger Breccien der alpinen Trias an Beispielen aus der Schweiz und Österreich: Geologisch-Paläontologische Mitteilungen Innsbruck, v. 1, no. 7, 11 p.

Lačný, A., Putiška, R., Dostál, I., and Kušnirák, D., 2012, Využitie metódy ERT pri prieskume jaskýň v Havranej skale (Plavecký kras): Slovenský Kras (Acta Carsologica Slovaca), v. 50, no. 1, p. 41-60.

Loke, M.H., and Barker, R.D., 1996, Rapid least-squares inversion of apparent resistivity pseudosections by a quasi-Newton method: Geophysical Prospecting, v. 44, p. 131-152. doi:10.1111/j.13652478.1996.tb00142.x.

Margiotta, S., Negri, S., Parise, M., and Valloni, R., 2012, Mapping the susceptibility to sinkholes in coastal areas, based on stratigraphy, geomorphology and geophysics: Natural Hazards, v. 62, no. 2, p. 657-676. doi:10.1007/s11069-012-0100-1.

Mochales, T., Casas, A.M., Pueyo, E.L., Pueyo, O., Román, M.T., Pocoví, A., Soriano, M.A., and Ansón, D., 2008, Detection of underground cavities by combining gravity, magnetic and ground penetrating radar survey: A case study from the Zaragoza area, NE 
Spain: Environmental Geology, v. 53, p. 1067-1077. doi:10.1007/ s00254-007-0733-7.

Nyquist, J.E., Peake, J.S., and Roth, M.J.S., 2007, Comparison of an optimized resistivity array with dipole-dipole soundings in karst terrain: Geophysics, v. 72, no. 4, p. F139-F144. doi:10.1190/ 1.2732994 .

Parise, M., and Gunn, J., eds., 2007, Natural and Anthropogenic Hazards in Karst Areas: Recognition, Analysis and Mitigation, London, Geological Society, London, Special Publication no. 279, 202 p.

Parise, M., and Lollino, P., 2011, A preliminary analysis of failure mechanisms in karst and man-made underground caves in Southern Italy: Geomorphology, v. 134, no. 1-2, p. 132-143. doi:10.1016/ j.geomorph.2011.06.008.

Pepe, P., Pentimone, N., Garziano, G., Martimucci, V., and Parise, M., 2013, Lessons learned from occurrence of sinkholes related to manmade cavities in a town of southern Italy, in Land, L., Doctor, D.H., and Stephenson, J.B., eds., Proceedings of the 13th Multidisciplinary Conference on Sinkholes and the Engineering and Environmental Impacts of Karst, Carlsbad (New Mexico, USA), 6-10 May 2013, Carsbad, National Cave and Karst Research Institute, p. 393-401.

Polák, M., Plašienka, D., Kohút, M., Putiš, M., Bezák, V., Filo, I., Olšavský, M., Havrila, M., Buček, S., Maglay, J., Elečko, M., Fordinál, K., Nagy, A., Hraško, L., Németh, Z., Ivanička, J., and Broska, I.,
2011, Geologická mapa regiónu Malých Karpát v M 1:50 000 (Geological map of the Male Karpaty Mts. Region, 1:50 000), Bratislava, MŽP SR, Státny geologický ústav Dionýza Štúra.

Putiška, R., Dostál, I., Mojzeš, A., Gajdoš, V., Rozimant, K., and Vojtko, R., 2012a, The resistivity image of the Murán fault zone (Central Western Carpathians) obtained by electrical resistivity tomography: Geologica Carpathica, v. 63, no. 3, p. 233-239. doi:10.2478/v10096012-0017-3.

Putiška, R., Nikolaj, M., Dostál, I., and Kušnirák, D., 2012b, Determination of cavities using electrical resistivity tomography: Contributions to Geophysics and Geodesy, v. 42, no. 2, p. 201-211.

Schaad, W., 1995, Die Entstehung von Rauhwacken durch die Verkarstung von Gips: Eclogae Geologicae Helvetiae, v. 88, p. 59-90.

Waltham, T., Bell, F.G., and Culshaw, M.G., 2005, Sinkholes and Subsidence: Karst and Cavernous Rocks in Engineering and Construction. Chichester, UK, Praxis, 382 p.

White, W.B., 1990, Surface and near-surface karst landforms, in Higgins, C.G., and Coates, D.R., eds., Groundwater Geomorphology: The Role of Subsurface Water in Earth-Surface Processes and Landforms: Geological Society of America Special Paper 252, p. 157-175.

Zhou, W., Beck, B.F., and Adams, A.L., 2002, Effective electrode array in mapping karst hazards in electrical resistivity tomography: Environmental Geology, v. 42, p. 922-928. doi:10.1007/s00254-002-0594-z. 